\section{THE ROYAL COMMISSION ON WELSH MONUMENTS.}

THE first meeting of the Royal Commission on Ancient Welsh Monuments in Wales and Monmouthshire, was held in London on Friday, September II. Sir John Rhys, the Chairman of the Commission, after recounting the terms of reference, expressed his views as to the nature and scope of the Commission's work, and the lines upon which he proposed to direct its course.

"The work," he said, "would not be difficult if they proceeded from county to county and parish to parish, and simply drew up a bare list or. inventory of the objects of antiquarian and historical interest therein; but it was clear that such an inventory would be of no scientific value unless those objects were classified according to their character, intention, and probable date. It was only by a comparative method that they could hope to answer many of the questions with which they would be confronted, and it was desirable, therefore, that the classificatory system adopted by the Commission should be uniform with that in use by other commissions of a similar character. With regard to ancient earthworks, he thought it would be better to adopt the divisions suggested by the Congress of Archæological Societies in Igor. No specific power was given to the Commission under which they could engage in exploratory work for the purpose of ascertaining the age or character of any particular object, though it was difficult to see how without such guidance the classification of some objects could be determined satisfactorily."

He thought the county might be taken as a proper area unit. It is proposed to publish county inventories as soon as they are finished, and thus make them available for use at once. A preliminary list of the monuments within a given county would be framed from the 6-inch Ordnance map, and supplemented by inquiries that would be made through the local secretaries and primary schools. He suggested that the sympathy and the assistance of the county councils should be sought, and that circulars should be sent to the numerous class of bards and literati, and those whom the secretaries might find interested in the work. A bibliography on the subject would be collected, and personal visits must be undertaken to the various monuments within the counties. "Those visits could be undertaken by the secretaries. It was inevitable that in the course of such work it would be found that there were monuments that, owing to the complexity of structure and other matters, must be inspected by the whole Commission, and they would have to settle points that were important and also disputed."

The points cited from the chairman's address show what a great work the Commission has undertaken. It is thought that it will take three years at least to complete its task.

Like all bodies representative of the whole Welsh nation, the Commission is very strong on the literary side, and the bibliography and all historical matter will be of the greatest value to archæologists. There is little reason to be dissatisfied with the purely scientific element in the Commission, providing that important scientific methods will not be decided upon merely by a show of hands. The chairman's remarks warrant our highest expectations as to the thoroughness with which the work will be done.

Though the Commission is not specifically empowered to engage in exploratory work, it is clear by the proposal to make personal visits to the monuments that a work more urgent and far easier than any explanatory work can and most likely will be done, namely, an astronomical survey of all monuments which lend themselves to such an inquiry. No body of experts would make such visits without an ordinary compass. All that would be required in order to make the astronomical survey of sufficient value would be a clino-compass, and sufficient acquaintance with the "run" of astronomical monuments to be able to find out alignments, to take their orientation and the height of the horizon in the same direction.

At least three members of the Commission are deeply interested in the astronomical inquiry, and the secretary, Mr. Edward Owen, has already acquainted himself with the results so far obtained in Wales. Neither expense nor time-for a monument could be surveyed in a few minutes-could be pleaded as a reason for neglecting such a golden opportunity of securing comparative data of the greatest interest. It is to be hoped that at the next meeting of the Commission this important matter will be definitely dealt with.

Now that little Wales has been so generously provided for in the matter of this Commission, the question crops up very naturally, Why has not larger England obtained the same privilege?

\section{JOHN GRIFFITH.}

DR. SVEN HEDIN'S LATEST EXPLORATIONS.

$A \mathrm{~N}$ interesting account of Dr. Sven Hedin's latest journey in Tibet is to be found in the Times of September 17 and 18 , from which we gather the following particulars of the discoveries made by this intrepid explorer.

On March 8 last he came across stone houses, the residence of the local chief, but only a high lama from Lhasa was present, living in a great tent, which was a movable temple, similar to that of the Kalmucks on the Volga, indicating that religious rites are performed among the nomads.

Dr. Sven Hedin then went along the northern edge of the great tract between latitudes $30^{\circ}$ and $32^{\circ}$, stretching from his old route to the Brahmaputra, which was the great object of his journey. He marched due south, crossing several ranges all running east and west. He passed the enormous ice mountain of Shakangsham on the east, from which flowed the big river. Thence he went over the Ladang pass into the open valley, and the Bongba province, which no European had ever before entered, lay open before him.

At this point great precautions had to be taken in consequence of the suspicions of the Tibetans, and the leader narrowly escaped detection whilst making barometric observations. However, the danger was averted by the march being diverted to the mountainous country where Lake Chunitso was discovered. Two more ranges were crossed, and then the open plain was reached, bounded southwards by a great mountain range, 2000 miles long, which stretches east and west.

Dr. Sven Hedin was rewarded by discovering the continuity of the chain. He found also that the course of Chartatsango, a big effluent of the Brahmaputra, had been wrongly marked on the maps.

After encountering serious opposition, and lis caravan being divided, Dr. Sven Hedin left Bis on May 5, and travelling due north crossed a pass of 1900 feet in the Great Range, and made for Lake Tederam, the existence of which Nain Singh reported in 1873 , its real name being Terenam. He found the lake. to be long, narrow, and sait, and entirely different from its representation on the map.

$\mathrm{He}$ then turned westward and visited the Mending

NO. 2030, VOL. 78$]$ 